Научная статья

УДК 34:616-02

DOI 10.18101/2658-4409-2021-2-10-14

\title{
ПРОБЛЕМА СОВЕРШЕНСТВОВАНИЯ КВАЛИФИКАЦИИ ПРЕСТУПЛЕНИЙ, СОВЕРШЕННЫХ МЕДИЦИНСКИМИ РАБОТНИКАМИ
}

\author{
(c) Раднаева Юлия Владимировна \\ кандидат юридических наук, \\ заместитель прокурора Железнодорожного района города Улан-Удэ \\ Россия, 670002, г. Улан-Удэ, ул. Комсомольская, $9 б$ \\ julbudaeva@mail.ru
}

\begin{abstract}
Аннотация. В работе освещены некоторые актуальные проблемы расследования и квалификации преступлений, совершенных медицинскими работниками в процессе оказания медицинской помощи пациентам. Автор на основании конкретного примера судебной практики иллюстрирует особенности его правовой оценки. Конкретизированы сложности, возникающие при установлении наличия либо отсутствия объективной стороны анализируемого состава преступления. Также анализируются проблемы установления причинно-следственной связи между ятрогенным дефектом медицинского воздействия и наступившими неблагоприятными последствиями. Статья посвящена характеристике ненадлежащего исполнения медицинским работником своих профессиональных обязанностей.
\end{abstract}

Ключевые слова: уголовное законодательство, ятрогенные преступления; качество медицинской помощи; ответственность медицинских работников; ятрогенный дефект

\section{Для цитирования}

Раднаева Ю. В. Проблема совершенствования квалификации преступлений, совершенных медицинскими работниками // Вестник Бурятского государственного университета. Юриспруденция. 2021. Вып. 2. С. 10-14.

Уголовное законодательство Российской Федерации не предусматривает понятия «ятрогенное преступление». Ятрогения — это любые нежелательные или неблагоприятные последствия профилактических, диагностических и лечебных вмешательств либо процедур, которые приводят к нарушениям функций организма, ограничению привычной деятельности, инвалидизации или смерти; осложнения медицинских мероприятий, развившиеся в результате как ошибочных, так и правильных действий или бездействий врача.

Вопросы юридической оценки действий медицинских работников за неоказание или ненадлежащее оказание медицинской помощи всегда вызывают споры у правоприменителей. Сложности возникают при установлении наличия либо отсутствия объективной стороны того или иного состава преступления. Так, в 2018 г. прокуратурой района в порядке ст. 37 УПК РФ в органы дознания был направлен материал по факту причинения тяжкого вреда здоровью потерпевшей при проведении тонкоигольной аспирационной биопсии молочной железы. В ходе проверки было установлено, что врач-онколог, проводя тонкоигольную аспирационную биопсию молочной железы под контролем УЗИ с участием УЗИ-специалиста, совершил прокол плевральной полости и легкого потерпевшей, что привело 
Ю. В. Раднаева. Проблема совершенствования квалификации преступлений, совершенных медицинскими работниками

к развитию левостороннего пневмоторакса, причинившего тяжкий вред здоровью человека по признаку опасности для жизни. По данному факту орган дознания возбудил дело по ч. 2 ст. 118 УК РФ в отношении неустановленного лица.

В ходе расследования возникли вопросы о причастности врачей к совершению преступления, квалификации их действий. Так, позиция врача-онколога заключалась в том, что он, не имея допуска к проведению УЗИ, действовал при пункции по указаниям врача-узиста, узист, в свою очередь, пояснил, что контролировал введение иглы и что прокол в данном случае маловероятен.

Объективную сторону состава преступления, предусмотренного ч. 2 ст. 118 УК РФ, в данном случае образует причинение тяжкого вреда вследствие ненадлежащего исполнения лицом своих профессиональных обязанностей медицинским работником, то есть когда медицинская помощь оказана ненадлежаще, не в полном объеме, не на должном профессиональном уровне.

Согласно методическим рекомендациям «Порядок проведения судебномедицинской экспертизы и установления причинно-следственных связей по факту неоказания или ненадлежащего оказания медицинской помощи», утвержденным ФГБУ «РЦСМЭ» Минздрава России от 21.06.2017 г., ненадлежащее оказание медицинской помощи пациенту - это оказание медицинской помощи пациенту не в соответствии с общепринятыми порядками оказания медицинской помощи и стандартами медицинской помощи, утвержденными Министерством здравоохранения Российской Федерации, клиническими рекомендациями (протоколами лечения) по вопросам оказания медицинской помощи, разработанными и утвержденными медицинскими профессиональными некоммерческими организациями, в том числе технические и лечебно-диагностические ошибки при оказании медицинской помощи пациенту. В нашем случае прокол легкого и плевральной полости относится к технической ошибке, так как, согласно заключению эксперта, прокол был совершен при нарушении техники проведения биопсии. Также экспертом установлено, что при проведении операции были неверно интерпретированы данные УЗИ. Последующие экспертизы также указали на нарушение техники проведения биопсии и на отсутствие должного визуального контроля за продвижением биопсийной иглы к патологическому очагу на видеодисплее.

В ходе расследования установлено, что нет нормативных актов, регулирующих проведение тонкоигольной аспирационной биопсии. Пунктом 4.3 письма Минздрава России от 7 ноября 2018 г. № 15-4/10/2-7235 «О направлении клинических рекомендаций "Доброкачественная дисплазия молочной железы" (вместе с Клиническими рекомендациями (протоколом лечения)», утвержденными Российским обществом акушеров-гинекологов 02.11.2018), предусмотрена тонкоигольная аспирационная биопсия. В письме указано, что тонкоигольная аспирационная биопсия позволяет получить материал, пригодный для цитологического исследования. Тонкоигольная аспирационная биопсия предусмотрена приказом Минздрава России от 13.10.2017 г. № 804н (ред. от 16.04.2019) «Об утверждении номенклатуры медицинских услуг». Также имеются критерии, утвержденные приказом Министерства здравоохранения Российской Федерации от 10 мая 2017 г. № 203н «Об утверждении критериев оценки качества медицинской помощи». Указанные критерии сформированы на основе порядков оказания медицинской 
помощи и стандартов медицинской помощи, утвержденных Министерством здравоохранения Российской Федерации, клинических рекомендаций (протоколов лечения) по вопросам оказания медицинской помощи, разработанных и утвержденных медицинскими профессиональными некоммерческими организациями, применяются при оказании медицинской помощи в медицинских и иных организациях, осуществляющих медицинскую деятельность, имеющих лицензию на медицинскую деятельность, и носят общий рекомендательный характер. Критерии качества определяют вред, причиненный здоровью человека, как нарушение анатомической целости и физиологической функции организма человека в результате воздействия одного или нескольких внешних повреждающих факторов (физических, химических, биологических, психических) либо неоказания помощи больному без уважительных причин лицом, обязанным ее оказывать в соответствии с законом или со специальным правилом, либо вследствие ненадлежащего исполнения лицом своих профессиональных обязанностей.

Таким образом, согласно медицинским критериям, вред в виде нарушения анатомической целостности органов человека был допущен в результате ненадлежащего исполнения лицом своих профессиональных обязанностей. Соответственно, объективную сторону анализируемого состава преступления образует прокол стенки плевральной полости и легкого потерпевшей, который был осуществлен врачом-онкологом. Причинная связь в уголовном праве — это объективно существующая связь между преступным деянием и наступившими общественно опасными последствиями, наличие которой является обязательным условием для привлечения лица к уголовной ответственности. Данная причинная связь всегда должна быть прямой. В случае с действием врача-онколога причинная связь налицо. Установить причинную связь между действием или бездействием врача УЗИ и совершенным проколом врачом-онкологом в данном случае невозможно. Опровергнуть доводы врача УЗИ о том, что им надлежащим образом была оказана медицинская помощь и что он не утерял контроль во время проведения биопсии, могут только видеозапись операции на УЗИ-экране и проведенная по ней экспертиза. Только так можно установить вину и причастность специалиста УЗИ к совершенному преступлению.

В настоящее время дело по обвинению врача-онколога направлено в суд для рассмотрения его по существу.

Вину в совершении инкриминируемого преступления врач-онколог М. в ходе расследования и судебного заседания не признала, после исследования всех доказательств по делу сторона защиты заявила ходатайство о возращении дела прокурору в порядке ст. 237 УПК РФ в связи с имеющимися нарушениями, что в связи с некорректным изложением обвинения М. лишена возможности защищаться, так как в обвинении указано, что М. обвиняется в проведении тонкоигольной аспирационной биопсии, когда как врачами М. и Д. проводилась иная операция - тонкоигольная аспирационная биопсия под контролем УЗИ, и что в обвинении не указан дефект медицинской помощи, который совершила М. Из ходатайства следует, что сторона защиты бремя вины за причинение тяжкого вреда здоровья перекладывает на врача УЗИ, контролировавшего проведение биопсии. С таким выводом мы не можем согласиться, доводы о виновности врача-онколога, непосредственно 
Ю. В. Раднаева. Проблема совершенствования квалификации преступлений, совершенных медицинскими работниками

выполнявшего манипуляции с иглой и допустившего прокол, приведены выше. Доводы защиты о том, что стороной обвинения неправильно указаны фактические обстоятельства, также несостоятельны, так как, согласно ранее приведенному Письму Минздрава России от 07.11.2018 N 15-4/10/2-7235 «О направлении клинических рекомендаций «Доброкачественная дисплазия молочной железы», утвержденному Российским обществом акушеров-гинекологов 2 ноября 2018 г., операция, проводимая врачом-онкологом и врачом-узистом на молочной железе потерпевшей, называется «тонкоигольная аспирационная биопсия». Тонкоигольная аспирационная биопсия под контролем УЗИ предусмотрена клиническими рекомендациями Минздрава России при проведении биопсии при раке гортани, раке щитовидной железы, раке полового органа. Также несостоятельны доводы стороны защиты о некорректном изложении обвинения. Врач М. обвиняется в том, что совершила дефект оказания медицинской помощи в виде прокола плевральной полости и легкого потерпевшей, приведшего к развитию пневмоторакса. Объективную сторону преступления, предусмотренного ч. 2 ст. 118 УК РФ, образует именно прокол, допущенный врачом-онкологом при оказании медицинской помощи. Слово «дефект» в данном случае используется в своем прямом значении как недостаток, ошибка, повреждение. Специальных познаний для определения наличия дефекта при оказании медицинской помощи не требуется.

На основании изложенного считаем, что ходатайство о возвращении дела прокурору не подлежит удовлетворению. Нарушений, препятствующих вынесению итогового решения судом, не имеется.

\section{Литература}

1. Веллер Э. М., Наумов А. Н. Савельев Р. Проблемы уголовной ответственности медицинских работников. Санкт-Петербург, 2004. Текст : непосредственный.

2. Кибальник А. Г., Старостина Я. В. Актуальные проблемы уголовной ответственности медицинских работников : монография. Москва, 2006. Текст : непосредственный.

3. Сергеев Ю. Д., Ерофеев В. Неблагоприятный исход оказания медицинской помощи. Москва, 2000. Текст : непосредственный.

4. Сергеев Ю. Д., Мохов А. А. Ненадлежащее врачевание: возмещение вреда здоровью и жизни пациента. Москва : Гэотар-медия, 2007. Текст : непосредственный.

Статья поступила в редакциюю 15.04.2021; одобрена после рецензирования 11.05.2021; принята к публикачии 22.06.2021.

\section{PROBLEM OF IMPROVING THE CLASSIFICATION OF CRIMES COMMITTED BY MEDICAL WORKERS}

Yulia V. Radnaeva

Cand. Sci. (Law),

Deputy Prosecutor of Ulan-Ude Zheleznodorozhny District

9b Komsomolskaya St., Ulan-Ude 670002, Russia

julbudaeva@mail.ru 
Abstract. The article is devoted to the characteristic of improper execution of professional duties by a medical worker, it considers some topical issues of investigation and classification of crimes committed by medical workers in the process of providing medical care to patients. Based on a particular case of judicial practice we have illustrated the peculiarities of its legal assessment. We also considered the difficulties arising in determining the presence or absence of the objective aspect of the analyzed corpus delicti, and the problems of establishing a causal relationship between the iatrogenic defect in medical exposure and the resulting adverse consequences.

Keywords: criminal legislation, iatrogenic crime; quality of medical care; responsibility of medical professionals; iatrogenic defect

For citation

Radnaeva Yu. V. Problem of Improving the Classification of Crimes Committed by Medical Workers. Bulletin of Buryat State University. Law. 2021; 2: 10-14 (In Russ.).

The article was submitted 15.04.2021; approved after reviewing 11.05.2021; accepted for publication 22.06.2021. 